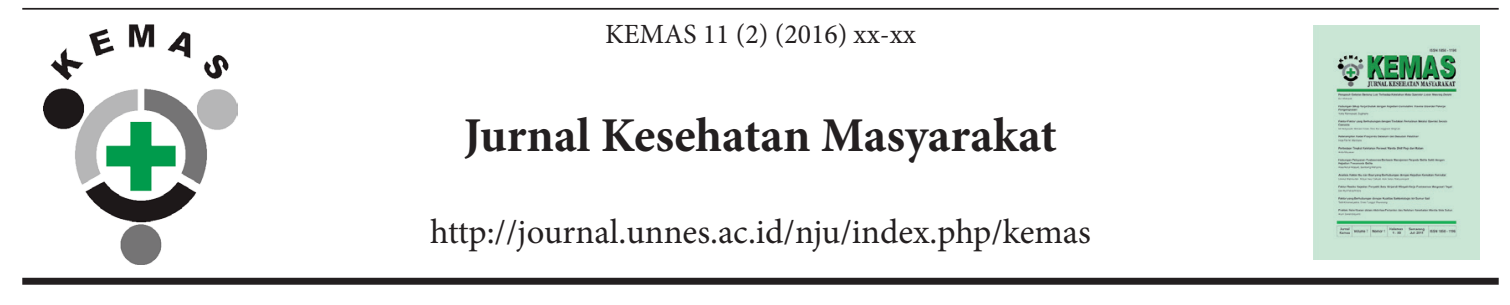

\title{
RISIKO KESEHATAN PAJANAN BENZENA, TOLUENA, DAN XYLENA PETUGAS PINTU TOL
}

\author{
Eko Handoyo ${ }^{1}$, Bambang Wispriyono ${ }^{2 \bowtie}$ \\ ${ }^{1}$ Dinas Kesehatan Kota Tangerang, Tangerang Banten, Indonesia. \\ ${ }^{2}$ Departemen Kesehatan Lingkungan Fakultas Kesehatan Masyarakat Universitas Indonesia
}

\begin{tabular}{l} 
Info Artikel \\
\hline Sejarah Artikel: \\
Diterima 15 September 2015 \\
Disetujui 1 Desember 2015 \\
Dipublikasikan Januari 2016 \\
\hline Keywords: \\
Health Risk; Ben- \\
zene; Toulene; Xylene. \\
\hline DOI \\
http://dx.doi.org/10.15294/ \\
kemas.v11i1.3521 \\
\end{tabular}

\begin{abstract}
Abstrak
Efek negatif dari polusi udara terhadap kesehatan manusia banyak diteliti termasuk polusi akibat sistem transportasi. Emisi kendaraan bermotor menghasilkan Benzena, To luena dan Xylena (BTX) yang merupakan bahan kimia yang bersifat karsinogenik dan petugas pintu tol merupakan kelompok berisiko terpajan BTX. Penelitian tahun 2015 ini bertujuan mengetahui risiko kesehatan akibat pajanan BTX pada petugas pintu tol. Desain penelitian adalah cross-sectional dengan pendekatan Analisis Risiko Kesehatan Lingkungan (ARKL) dan faktor-faktor antropometri. Hasil penelitian menunjukkan pada pintu tol rata-rata konsentrasi (mean+SD) benzena sebesar 0,00167+0,000056 mg/ $\mathrm{m}^{3}$, toluena sebesar $0,00124+0.000049 \mathrm{mg} / \mathrm{m}^{3}$, dan xylena sebesar $0,00147+0,000063$ $\mathrm{mg} / \mathrm{m}^{3}$. Pada kantor administrasi konsentrasi tidak terdeteksi oleh alat (Method Detection Limit). Rata-rata risiko non karsinogenik (RQ) BTX pada petugas pintu tol lebih tinggi secara signifikan dibandingkan dengan rata-rata RQ BTX petugas administrasi. Risiko kesehatan non karsinogenik dan karsinogenik belum menunjukkan adanya risiko kese-hatan yang signifikan. Upaya pencegahan berupa pengelolaan manajemen risiko untuk pengendalian risiko bahan berbahaya di lingkungan perlu ditingkatkan.
\end{abstract}

HEALTH RISKS BENZENE, TOLUENE, AND XYLENE OF TOLL GATE OFFICER

\begin{abstract}
The researches of BTX (Benzene, Toluene and Xylene) related to the health impacts have been done and published in any publications. One of the risk groups is toll gate's workers who have been exposed every day with BTX. The study in 2015 used cross-sectional design with environmental health risk analysis to determine the magnitude of health risks of BTX on the toll gate. The results showed at the toll workers's respondents have benzene concentration $0.00167+0.000056 \mathrm{mg} / \mathrm{m}^{3}$, toluene $0.00124+0.000049 \mathrm{mg} / \mathrm{m}^{3}$ and xylene $0.00147+0,000063 \mathrm{mg} / \mathrm{m}^{3}$ respectively, while in the administrative office's respondents, BTX was undetectable (Minimum Detection Limit). The average RQ of toll gate respondents was significantly higher than administrative office's respondents. In conclusion, the risk of all workers have the $R Q \leq 1$. Non carcinogenic and carcinogenic health risks to all toll gate's workers recently have not shown any risk yet. Nevertheless, risk management system should be developed and improved.
\end{abstract}

(c) 2016 Universitas Negeri Semarang 


\section{Pendahuluan}

Perlindungan dan pengelolaan lingkungan hidup menyebutkan bahwa perlindungan dan pengelolaan lingkungan hidup bertujuan untuk menjamin keselamatan, kesehatan dan kehidupan manusia dan setiap orang berhak mendapatkan lingkungan yang sehat bagi pencapaian derajat kesehatan yang setinggi - tingginya, sebagai investasi bagi pembangunan sumberdaya manusia yang produktif secara sosial dan ekonomis.

Pertumbuhan pembangunan seperti industri, transportasi, disamping memberikan dampak positif namun disisi lain akan memberikan dampak negatif dimana salah satunya berupa pencemaran udara dan kebisingan baik yang terjadi didalam ruangan (indoor) maupun di luar ruangan (outdoor) yang dapat membahayakan kesehatan manusia dan terjadinya penularan penyakit. Aktifitas transportasi khususnya kendaraan bermotor merupakan sumber utama pencemaran udara di daerah perkotaan dan merupakan salah satu faktor risiko terjadinya berbagai penyakit karena asap yang dilepaskan dari kendaraan bermotor mengandung unsur senyawa kimia yang berbahaya bagi kesehatan manusia, maupun kondisi lingkungan. Hal ini terlihat dari adanya bahan-bahan kandungan polutan dan metabolit dalam tubuh indvidu yang terpajan (Ukai, 2007: Guo, 2013).

Perkembangan sektor transportasi memberikan kemudahan masyarakat untuk melakukan aktifitas dan saling terhubung. Namun di sisi lainnya, dampak negatif dari pertumbuhan kendaraan bermotor juga dirasakan oleh masyarakat. Kemacetan dan pencemaran udara akibat emisi gas buangan kendaraan bermotor menjadi masalah tersendiri yang dihadapi. Pencemaran udara memberikan dampak terhadap kesehatan manusia seperti gangguan pernafasan, infeksi saluran pernafasan, hingga memicu terjadinya kanker.

Beberapa zat pencemar di udara akibat aktifitas kendaraan bermotor diantaranya karbon monoksida (CO), nitrogen oksida $\left(\mathrm{NO}_{\mathrm{x}}\right)$, metana $\left(\mathrm{CH}_{4}\right)$, sulfur dioksida $\left(\mathrm{SO}_{\mathrm{x}}\right)$, dan hidrokarbon. Benzena, Toluena dan xylena (BTX) merupakan beberapa jenis pencemar udara yang merupakan senyawaan Polisiklik
Aromatik Hidrokarbon (PAH). PAH terbentuk akibat pembakaran tidak sempurna bahan organik, menyebar pada lingkungan dan berbentuk campuran. Sumber utama pajanan PAH ke manusia berasal dari lingkungan pekerjaan, perokok pasif dan aktif (Suzuki, 2007), makanan dan air serta polusi udara (Nethery, 2012).

BTX merupakan Volatile Organic Compound (VOC), senyawa yang mengandung karbon yang menguap pada tekanan dan temperatur tertentu atau memiliki tekanan uap yang tinggi pada temperatur ruang. VOC yang paling umum dikenal adalah senyawaan golongan pelarut (solvents), VOC jenis lainnya banyak digunakan seperti monomer dan pewangi (Tunsaringkar, 2012). BTX adalah bahan kimia termasuk golongan bahan kimia bersifat toksik terhadap kesehatan, baik yang bersifat karsinogenik atau pemicu timbulnya kanker (Gammon, 2008; Reid, 2012; White, 2014), dan meningkatkan stress oksidatif (Bae, 2010) maupun non karsinogenik seperti mempengaruhi sistem hematopoietik, susunan saraf pusat dan sistem reproduksi (Han, 2011). Sifat toksik BTX dalam pajanan tingkat tinggi menyebabkan gejala neurotoksik. Pajanan terus-menerus kadar tinggi BTX dapat mengakibatkan kerusakan pada sumsum tulang manusia, kerusakan DNA pada sel mamalia, kerusakan sistem kekebalan tubuh. Pajanan ringan menyebabkan denyut jantung tidak teratur, sakit kepala, pusing, mual dan bahkan pingsan jika pajanan dilanjutkan untuk waktu yang lama. Manifestasi awal dari toksisitas adalah anemia, leukositopenia, dan trombositopenia (Singh, 2012).

Pada pencemaran udara, dampak secara umum pajanan terus menerus dari polusi udara dapat menyebabkan kanker paru-paru, jantung, dan penyakit lainnya yang menjadi faktor risiko timbulnya kematian (Langrish, 2014). Pajanan benzena dan toluena juga dapat menurunkan kadar Leukocyte Telomere Length (LTL) (Hoxha, 2009). Pajanan 50 ppm toluena dapat meningkatkan induksi lipopolisakarda (LPS-induced) proliferasi sel tikus secara signifikan (Fujimaki, 2010), penurunan aktifitas enzim antioksidan secara signifikan, dan meningkatkan peroksidasi lemak dan kerusakan protein baik secara in vivo maupun 
in vitro (Karabulut, 2009). Efek utama yang dapat timbul dari menghirup uap xylena adalah depresi pada sistem syaraf pusat, dengan gejala seperti sakit kepala, pusing-pusing, mual dan muntah dan seperti halnya benzena, dapat mengakibatkan penurunan sel darah merah (anemia) (Kandyala, 2010).

DKI Jakarta adalah salah satu kota besar dengan tingkat polusi paling tinggi di Indonesia. Hal ini terlihat dengan menurunnya kualitas lingkungan akibat bahan pencemar yang dilepas oleh sumber pencemar ke lingkungan yang semakin banyak jenis dan jumlahnya. Udara merupakan salah satu media lingkungan yang meningkat pencemarannya diakibatkan oleh melonjaknya volume kendaraan bermotor yang menyebabkan tingkat polusi udara di DKI Jakarta semakin meningkat. Direktorat Lalu Lintas Polda Metro Jaya Subdit Registrasi dan Identifikasi Kendaraan (Regident) mencatat di tahun 2013 jumlah kendaraan di Jakarta dan sekitarnya mencapai 16 Juta unit.

Penelitian BTX pada berbagai aktivitas manusia telah banyak dilakukan seperti pengukuran BTX di Pompa Bensin (Tunsaringkarn, 2012) dan di daerah urban (Singh, 2012). Tingginya tingkat polusi di jalan raya khususnya di jalan tol di kota besar seperti Jakarta dan lamanya pajanan yang dialami oleh petugas jalan tol diperkuat lagi dengan tingkat kepatuhan petugas jalan tol dalam penggunaan Alat Pelindung Diri membuat petugas jalan tol memiliki risiko kesehatan baik tinggi. Namun demikian, masih sedikit penelitian dan publikasi ilmiah yang terkait dengan risiko kesehatan akibat pajanan BTX dari kendaraan bermotor khususnya risiko kesehatan pada petugas jalan tol. Tujuan penelitian ini adalah menganalisis risiko kesehatan akibat pajanan BTX pada petugas jalan tol.

\section{Metode}

Desain studi yang digunakan adalah cross-sectional dengan pendekatan Analisis Risiko Kesehatan Lingkungan (ARKL). Analisis Risiko adalah proses yang bertujuan untuk menghitung atau memperkirakan risiko pada suatu organisme sasaran, sistem atau populasi, termasuk identifikasi ketidak pastian yang menyertainya, setelah terpajan oleh agent tertentu, dengan memperhatikan karakteristik yang melekat pada agent yang menjadi perhatian dan karakteristik sistem sasaran yang spesifik. ARKL digunakan dalam penelitian ini untuk menghitung tingkat risiko kesehatan dan melakukan prediksi tingkat risiko kesehatan menurut proyeksi waktu pajanan jangka panjang akibat BTX.

Penelitian dilaksanakan pada periode bulan Maret-Juni 2014. Pengumpulan data dilakukan melalui wawancara untuk mendapatkan data antropometri pada petugas gerbang tol dan pengukuran konsentrasi BTX di udara di gerbang tol Kebun Jeruk, Jakarta. Sebagai kontrol pembanding, dilakukan wawancara pada pekerja administrasi yang bekerja di dalam ruang kantor dan pengukuran konsentrasi BTX pada kantor administrasi. 20 resresponden pada kelompok pekerja pintu tol terpajan BTX dan 15 responden pada kelompok pembanding yaitu total karyawan yang ada di bagian administrasi merupakan sampel responden. Jumlah sampel BTX udara diambil dari dua titik lokasi untuk masingmasing lokasi pintu tol dan kantor administrasi dengan masing-masing titik diukur sebanyak 3 kali pengukuran.

Pengukuran konsentrasi BTX udara dengan menggunakan metode pengukuran NIOSH 1501 (NIOSH, 2003) dengan bahan pipa pengabsosbsi karbon aktif (charcoal) yaitu dengan menggunaksan tehnik Gas Chromatography (GC).

Besar risiko BTX (RQ) dihitung melalui data konsentrasi BTX, jumlah asupan (I) dan nilai RfC dan CSF, seperti diuraikan pada Gambar 1.1. Perhitungan diakukan dengan pemodelan karakterisasi risiko berdasarkan model Louvar \& Louvar (1998), dengan cara menghitung tingkat risiko yang dinyatakan dengan Risk Quotient.

Perhitungan intake

$$
\text { Intake }(\mathrm{I})=\frac{\mathrm{C \times R \times t} \times f_{\mathrm{E}} \times D_{\mathrm{t}}}{W_{\mathrm{b}} \times t_{\mathrm{avg}}}
$$

\section{Keterangan :}

I $=\operatorname{asupan}(\mathrm{mg} / \mathrm{kg} / \mathrm{hari})$

$\mathrm{C}=$ konsentrasi toksikan udara $\left(\mathrm{mg} / \mathrm{m}^{3}\right)$

$\mathrm{R} \quad=$ laju inhalasi $\left(\mathrm{m}^{3} / \mathrm{jam}\right)$ 
Tabel 1. Hasil Konsentrasi BTX di Gerbang Tol Kebun Jeruk

\begin{tabular}{|c|c|c|c|c|}
\hline \multirow{2}{*}{ Parameter } & \multirow{2}{*}{$\mathrm{NAB} \mathbf{m g} / \mathrm{m}^{3}$} & \multicolumn{3}{|c|}{ Konsentrasi mg/m $\mathbf{m}^{3}$} \\
\hline & & Administrasi & Pintu Tol 1 & Pintu Tol 2 \\
\hline Benzena & & $<0,00120$ & 0,00163 & 0,00171 \\
\hline Mean & 1,59 & $<0,00120$ & & \\
\hline SD & & 0,00 & & \\
\hline Toluena & & $<0,00106$ & 0,00121 & 0,00128 \\
\hline Mean & 188 & $<0,00106$ & & \\
\hline SD & & 0,00 & & \\
\hline Xylena & & $<0,00126$ & 0,00143 & 0,00152 \\
\hline Mean & 434 & $<0,00106$ & & \\
\hline SD & & 0,00 & & \\
\hline
\end{tabular}

Sumber : Data Primer

$\begin{array}{ll}\mathrm{tE} & =\text { lama pajanan, jam/hari } \\ \mathrm{fE} & =\text { frekuensi pajanan, hari/tahun } \\ \mathrm{Dt} & =\text { durasi pajanan, tahun } \\ \mathrm{Wb} & =\text { berat badan }(\mathrm{kg}) \\ \mathrm{tavg} & =\text { perioda waktu rata-rata }\end{array}$

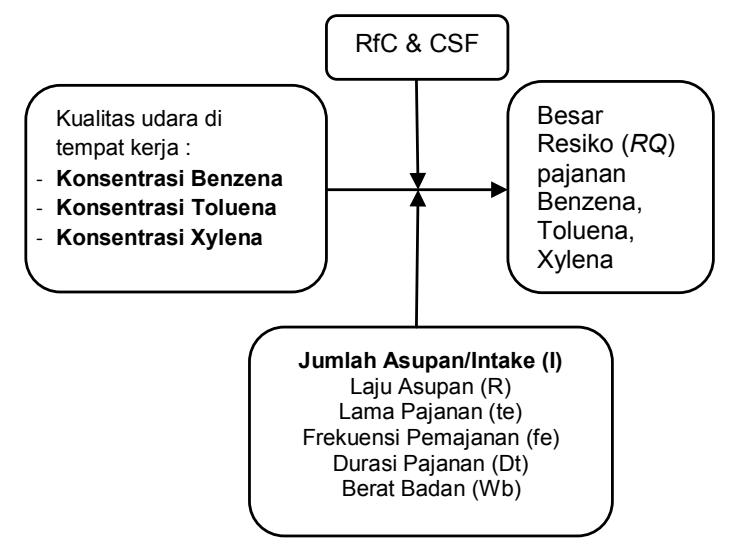

Gambar 1 Disain Konsep Penelitian

\section{Hasil dan Pembahasan}

Hasil pengukuran (Tabel 1) menunjukkan rata-rata konsentrasi $($ mean \pm SD) benzena sebesar $0,00167 \pm 0,000056 \mathrm{mg} / \mathrm{m}^{3}$, toluena sebesar $0,00124 \pm 0,000049 \mathrm{mg} / \mathrm{m}^{3}$ dan xylena sebesar $0,00147 \pm 0,000063 \mathrm{mg} / \mathrm{m}^{3}$, sementara pada pada kantor administrasi konsentrasi tidak terdeteksi oleh batas minimum pengukuran alat yang digunakan (Method Detection Limit).

Konsentrasi benzena berada di bawah nilai Minimal Risk Level (MRL) pajanan inhalasi benzene yang diturunkan oleh ATSDR sebesar pajanan akut $(\leq 14$ hari $)=0,009 \mathrm{ppm}$, pajanan sedang $(15-364$ hari $)=0,006 \mathrm{ppm}$, dan pajanan kronik $(\geq 365$ hari $)=0,003 \mathrm{ppm}$ (ATSDR, 2007). Konsentrasi benzena tersebut juga masih jauh di bawah NAB yang ditetapkan oleh Peraturan Menteri Tenaga Kerja dan
Transmigrasi Nomor Per.13/MEN/X/2011 tahun 2011 tentang nilai ambang batas faktor fisika dan faktor kimia di tempat kerja sebesar $1,59 \mathrm{mg} / \mathrm{m}^{3}$. Adapun konsentrasi toluena berada di bawah nilai Minimal Risk Level (MRL) untuk pajanan inhalasi kronis toluena yang diturunkan oleh ATSDR sebesar $2 \mathrm{ppm}$ $\left(7,6 \mathrm{mg} / \mathrm{m}^{3}\right)$ untuk pajanan akut, $1 \mathrm{ppm}(3,8$ $\mathrm{mg} / \mathrm{m}^{3}$ ) untuk pajanan kronik dan masih jauh di bawah NAB yang ditetapkan oleh Peraturan Menteri Tenaga Kerja dan Transmigrasi Nomor Per.13/MEN/X/2011 tahun 2011 tentang nilai ambang batas faktor fisika dan faktor kimia di tempat kerja sebesar $188 \mathrm{mg} / \mathrm{m}^{3}$. Konsentrasi xylena juga berada di bawah nilai Minimal Risk Level (MRL) untuk pajanan inhalasi akut sebesar 2 ppm, semi kronik sebesar 0,6 ppm, dan kronik sebesar 0,5 ppm (ATSDR, 2007). Konsentrasi xylena juga masih jauh di bawah NAB yang ditetapkan oleh Peraturan Menteri Tenaga Kerja dan Transmigrasi Nomor Per.13/ MEN/X/2011 tahun 2011 tentang nilai ambang batas faktor fisika dan faktor kimia di tempat kerja sebesar $434 \mathrm{mg} / \mathrm{m}^{3}$. Konsentrasi benzena sebesar $0,00167 \pm 0,000056 \mathrm{mg} / \mathrm{m}^{3}$, toluena sebesar $0,00124 \pm 0,000049 \mathrm{mg} / \mathrm{m}^{3}$ dan xylena sebesar $0,00147 \pm 0,000063 \mathrm{mg} / \mathrm{m}^{3}$. Konsentrasi ini masih jauh lebih kecil dibanding penelitian lain di Thailand, konsentrasi benzena 68.38 $\mu \mathrm{g} / \mathrm{m}^{3}$ (Tunsaringkan,2012). Sementara itu, konsentrasi toluena juga masih lebih kecil dibanding limit ACGIH sebesar $75 \mathrm{mg} / \mathrm{m}^{3}$ (ATSDR, 2007). Penelitian (Azari, 2012) menunjukkan kadar 0,16- 1,63 ppm untuk benzena dan 0,2-2,72 ppm untuk toluena pada petugas depot pengolahan bahan bakar minyak sementara pada kelompok control nilai BTEX di bawah limit deteksi pada metode yang 
Tabel 2. Data Antropometri Pekerja di Gerbang Tol Kebun Jeruk

\begin{tabular}{llcccc}
\hline \multicolumn{1}{c}{ Variabel } & \multicolumn{1}{c}{ Pekerjaan } & Mean & SD & Median & Nilai-p \\
\hline \multirow{2}{*}{ Umur } & Administrasi & 46,80 & 3,968 & 48 & 0,000 \\
\multirow{3}{*}{ Berat Badan } & Petugas Tol & 39,90 & 3,796 & 38,5 & \\
& Administrasi & 70,67 & 14,666 & 67 & 0,519 \\
\multirow{3}{*}{ Frekuensi Pajanan } & Petugas Tol & 67,90 & 10,457 & 68,5 & \\
\multirow{2}{*}{ Durasi Pajanan } & Administrasi & 239,20 & 32,888 & 260 & 0,000 \\
& Petugas Tol & 246,45 & 25,936 & 260 & \multirow{2}{*}{0,000} \\
Lama Pajanan & Administrasi & 25,93 & 3,555 & 27 & \multirow{2}{*}{0,005} \\
& Petugas Tol & 17,95 & 3,748 & 17.5 & 2 \\
\hline
\end{tabular}

Sumber : Data Primer

digunakan.

Hasil analisis memperlihatkan bahwa dari 20 petugas tol mempunyai rata-rata frekuensi pajanan 246,45 hari/tahun, durasi pajanan 17,95 tahun dan lama pajanan \pm 8 jam/ hari, sedangkan pada 15 petugas administrasi rata-rata frekuensi pajanan 239,20 hari/tahun, durasi pajanan 25,93 tahun dan lama pajanan $\pm 2,40 \mathrm{jam} / \mathrm{hari}$. Hasil penelitian menunjukkan terdapat perbedaan frekuensi, durasi dan lama pajanan antara antara petugas tol dan administrasi (semua $\mathrm{p}<0,05$ ).

Hasil uji t menunjukan hasil bahwa nilai$\mathrm{p}$ (sig.) umur adalah $0,0001(\mathrm{p}<0,05)$ untuk uji 2-sisi dan disimpulkan bahwa secara statistik rata-rata umur petugas tol dan administrasi berbeda bermakna. Sementara itu, untuk berat badan nilai-p(sig) adalah 0,519 ( $\mathrm{p}>0$, 05) disimpulkan bahwa berat badan petugas administrasi dan pada petugas tol tidak ada perbedaan yang bermakna secara statistik. Hal ini dapat dilihat pada Tabel 2.

Pajanan BTX terhadap seluruh total responden pekerja gerbang tol Kebun Jeruk tidak menunjukkan adanya risiko kesehatan non karsinogenik pada saat ini. Untuk memperkirakan faktor risiko di tahun-tahun yang akan datang, maka dilakukan perhitungan untuk pajanan BTX beberapa tahun yang akan datang. Tabel 3 memperlihatkan nilai RQ BTX pada tahun-tahun tersebut tidak menunjukkan adanya risiko kesehatan non karsinogenik $(\mathrm{RQ}<1)$. Pajanan benzena sebesar 0,00167 mg/ $\mathrm{m}^{3}$ melalui inhalasi pada responden dewasa yang bekerja di gerbang tol Kebun Jeruk dengan berat badan $68 \mathrm{~kg}$ pada petugas pintu tol dan $71 \mathrm{~kg}$ pada petugas administrasi, masih aman untuk frekuensi pajanan 350 hari/tahun hingga 30 tahun mendatang. Pajanan toluena sebesar
$0,000124 \mathrm{mg} / \mathrm{m}^{3}$ secara inhalasi pada responden dewasa yang bekerja di gerbang tol Kebun Jeruk dengan berat badan $68 \mathrm{~kg}$ pada petugas pintu tol dan $71 \mathrm{~kg}$ pada petugas administrasi, masih aman untuk frekuensi pajanan 350 hari/tahun hingga 30 tahun mendatang. Sementara itu, pajanan xylena sebesar $0,00147 \mathrm{mg} / \mathrm{m}^{3}$ secara inhalasi pada responden dewasa yang bekerja di gerbang tol kebun jeruk Jakarta barat dengan berat badan $68 \mathrm{~kg}$ pada petugas pintu tol dan $71 \mathrm{~kg}$ pada petugas administrasi, masih aman untuk frekuensi pajanan 350 hari/tahun hingga 30 tahun mendatang.

Risiko non karsinogenik dari pajanan senyawa BTX, dinyatakan sebagai RQ pada penelitian ini memiliki nilai lebih rendah dari tingkat bahaya referensi. Hal ini mencerminkan belum terlihat efek kesehatan yang merugikan pada saat terkini akibat pajanan BTX baik pada pekerja maupun petugas administrasi. Efek kesehatan yang timbul akibat pajanan BTX yang melampaui nilai ambang batas dan indeks pajanan biologis antara lain dapat gejala sakit kepala, fatigue dan iritasi pernafasan (Tunsaringkran, 2012), gangguan sistem hematopoietic, sumsum tulang, sistem saraf pusat, dan sistem reproduksi (Han, 2014).

Hasil perhitungan risiko karsinogenik tidak memperlihatkan risiko karsinogenik pajanan benzena pada responden mengacu pada nilai standar ECR (Excess Cancer Risk). ECR pada petugas pintu tol di gerbang tol kebun jeruk untuk pajanan benzena dengan nilai intake inhalasi sebesar $0,000046 \mathrm{mg} / \mathrm{kg} /$ hari, berat rata-rata $68 \mathrm{~kg}$ dan telah terpajan 242 dari/tahun selama 18 tahun nilai ECR benzena adalah 2,5E-06 yang artinya terdapat 2,5 kasus dalam 1000.000 atau $1 / 400.000$ orang yang berkembang menjadi kasus kanker atau 
Tabel 3. Hasil RQ Petugas Pintu Tol dan Petugas Administrasi

\begin{tabular}{lllccccc}
\hline \multirow{2}{*}{ Pajanan } & Pekerjaan & N & $\begin{array}{c}\text { RQ } \\
\text { Lifetime }\end{array}$ & SD & Mean RQ & $\begin{array}{c}\text { Mean } \\
\text { Rank }\end{array}$ & Nilai-p \\
\hline \multirow{2}{*}{ Benzena } & Administrasi & 15 & 0,0021 & 0,000960 & 0,00230 & 8,03 & 0,000 \\
& Petugas Tol & 20 & 0,0078 & 0,001794 & 0,00776 & 25,48 & \\
\multirow{2}{*}{ Toluena } & Administrasi & 15 & 0,00001 & 0,000006 & 0,000013 & 8,50 & 0,000 \\
& Petugas Tol & 20 & 0,00004 & 0,000008 & 0,000035 & 25,13 & \\
& Administrasi & 15 & 0,00066 & 0,003066 & 0,00729 & 8,23 & 0,000 \\
\hline
\end{tabular}

Sumber : Data Primer

terdapat 1 orang berisiko terkena kanker pada 400.000 orang populasi. Adapun ECR pada petugas administrasi di gerbang tol Kebun Jeruk untuk pajanan benzena dengan nilai intake inhalasi sebesar $0,0000079 \mathrm{mg} / \mathrm{kg} /$ hari dengan berat rata-rata $71 \mathrm{~kg}$ dan telah terpajan 239 dari/tahun selama 26 tahun adalah 4,4E07 yang artinya terdapat 4,4 kasus dalam 10.000.000 atau kurang lebih 1 / 2.500.000 orang yang berkembang menjadi kasus kanker atau terdapat 1 orang berisiko terkena kanker pada 2.500 .000 orang populasi. Kedua nilai ECR masih memiliki tingkat risiko acceptable atau aman dengan nilai ECR $\leq \mathrm{E}-4\left(10^{-4}\right)$ atau dinyatakan dengan $\mathrm{ECR} \leq 1 / 10.000$.

Walaupun nilai ECR pada pekerja dan petugas administrasi masih di bawah nilai ECR reference, namun nilai ECR pada pekerja lebih besar dari ECR petugas administrasi. Hal ini menunjukkan risiko efek kesehatan karsinogenik pekerja lebih tinggi dari petugas administrasi. Dalam penelitian lain, didapat nilai ECR yang lebih tinggi dibanding hasil penelitian ini, seperti penelitian di Thailand menunjukkan mean lifetime cancer risks untuk benzene sebesar $1,75 \times 10 \mathrm{E}-4$ dan RQ 0,600 (Tunsaringkran, 2012) dan pajanan benzena pada penelitian pajanan BTX di halte bis di Afrika Selatan sebesar a 3,78 × 10E-4 dengan rata-rata intake pajanan kronik $1,38 \times 10-3 \mathrm{mg}$ / $\mathrm{kg} /$ hari dan potensi kesehatan non karsinogenik pajanan benzena dan toluena (Moolla, 2015).

Berbeda dengan xylena dan toluena, benzena merupakan bahan yang terbukti bersifat karsinogenik (Huff, 2007), yang dapat berinteraksi dengan RNA, protein atau senyawaan molekuler lainnya yang dapat memicu efek karsinogenik tanpa langsung terkait dengan konsentrasi pajanan. Organisasi Kesehatan Dunia (WHO) memperkirakan 4 dari 1 juta penduduk berisiko terkena kanker leukemia bila terpajan $1 \mathrm{mg} / \mathrm{m}^{3}$ benzena (IARC, 2012).

Dalam penelitian ini, kebiasaan merokok pekerja (petugas told an administrasi) juga cukup rendah yaitu $60 \%$ responden tidak merokok (data tidak ditampilkan). Hal berpengaruh positif pada dampak pajanan. Perilaku sehat berupa olah raga rutin merupakan hal yang baik. Hasil penelitian lain menunjukkan, olah raga rutin 3 kali seminggu dengan durasi 20-30 menit setiap kali meningkatkan volume maksimal penyerapan oksigen (maximum oxygen uptake, VO2 max) (Nasrulloh, 2014).

\section{Penutup}

Dari hasil penelitian, disimpulkan besar risiko kesehatan pajanan BTX pada petugas tol belum menunjukkan adanya risiko kesehatan non karsinogenik $(\mathrm{RQ}<1)$ maupun risiko karsinogenik yang melampaui nilai standar referensi (ECR). Namun demikian, nilai ECR pada pekerja jalan tol lebih besar dari ECR petugas administrasi. Hal ini pekerja jalan tol memiliko risiko kesehatan karsinogenik yang lebih besar dibanding petugas adminstrasi. $\mathrm{RQ}<1)$. Saran dari penelitian ini adalah perlunya secara konsisten dilakukan pengelolaan manajemen risiko sebagai upaya pengendalian dampak kesehatan akibat pajanan pada pekerja penjaga pintu gerbang tol. Pengelolaan manajemen risiko yang dapat dilakukan dapat dilakukan dari berbagai aspek seperti aspek manajemen (pengaturan waktu kerja, pemberian suplemen makanan bergizi dan mengandung anti oksidan serta program olah raga yang teratur bagi pekerja), aspek KIE (Komunikasi, Informasi dan Edukasi) kepada pekerja dalam penggunaan APD, perilaku hidup sehat tanpa merokok dan rutin berolahraga atau berupa aspek teknologi 
(pengaturan emisi kendaraan layak jalan, pintu tol otomatis tanpa petugas).

\section{Daftar Pustaka}

Agency for Toxic Substances and Disease Registry (ATSDR). 2007. U.S. Department of Health and Human Services, Public Health Service, Atlanta - Georgia. http : //www.atsdr.cdc. gov/

Azari MR, et al. 2012. Occupational Exposure of Petroleum Depot Workers to BTEX Compounds. The International Journal of Occupational and Environmental Medicine. 3:39-44

Bae, S. et al. 2010. Exposures to particulate matter and polycyclic aromatic hydrocarbons and oxidative stress in schoolchildren. Environ Health Perspect. 118:579-83.

Fujimaki, H., et al. 2010. Different Sensitivity in Expression of Transcription Factor mRNAs in Congenic Mice Following Exposure to Low-level Toluene. Inhalation Toxicology. 22(11): 903-909.

Gammon, MD., Santella, RM. 2008. PAH, genetic susceptibility and breast cancer risk: an update from the long island breast cancer study project. Eur J Cancer. 44:636-640

Guo, Y., et al. 2013. Concentrations and Profiles of Urinary Polycyclic Aromatic Hydrocarbon Metabolites (OH-PAHs) in Several Asian Countries. Environ Sci Technol 47: 2932-2938

Han, X, et al. 2011. Association between urinary polycyclic aromatic hydrocarbon metabolites and sperm DNA damage: a population study in Chongqing, China. Environ Health Perspect. 119(5): 652-7.

Hoxha, M., et al. 2009. Association Between Leukocyte Telomere Shortening and Exposure to Traffic Pollution: A Cross-sectional Study on Traffic Officers and Indoor Office Workers. Environmental Heath. 8(41): 1-9.

Huff, J. 2007. Benzene-induced cancers: abridged history and occupational health impact. Int $J$ Occup Environ Health.13(2):213-21.

IARC (WHO). 2012. Diesel engine exhaust carcinogenic. In IARC Monographs on the Evaluation of Carcinogenic Risks to Humans; International Agency for Research on Cancer: Lyon, France. Volume 105

Karabulut, I., et al. 2009. Effect of Toluene on
Erythrocyte Membrane Stability Under In Vivo and In Vitro Conditions With Assessment of Oxidant/antioxidant Status. Toxicol Ind Health. 25(8): 545-550.

Kandyala, R., et al. 2010. Xylene: An overview of its health hazards and preventive measures. $J$ Oral Maxillofac Pathol. 14(1). 1-5.

Langrish, JP., Mills, NL. 2014. Air pollution and mortality in Europe. Lancet. 383(9919):758

Louvar FL and Louvar BD. 1998. Health and Environmental Risk Analysis: Fundamental with Apllication, Volume 2, New Jersey, Prentice Hall PTR

Moola R., Curtis CJ., Knight J. 2015. Occupational Exposure of Diesel Station Workers to BTEX Compounds at a Bus Depot Int. J. Environ. Res. Public Health. 12, 4101-4115

Nasrulloh, A. 2014. Program Physical Fitness Dalam Meningkatkan Kesehatan Paru. Jurnal Kesehatan Masyarakat (KEMAS). 10(1), 1-6

Nethery, E., et al. 2012. Urinary polycyclic aromatic hydrocarbons as a biomarker of exposure to PAHs in air: a pilot study among pregnant women. J Expo Sci Environ Epidemiol. 22:70

Reid, BC., et al. 2012. Research opportunities for cancer associated with indoor air pollution from solid-fuel combustion. Environ Health Perspect. 120:1495-1498.

Singh, A.K., Tomer, N., Jain, C.L. 2012. Monitoring, Assessment and Status of Benzene, Toluene and Xylene Pollution in the Urban Atmosphere of Delhi, India. Res.J.Chem.Sci. 2(4), 45-49

Suzuki, K., Yoshinaga, J. 2007. Inhalation and dietary exposure to polycyclic aromatic hydrocarbons and urinary 1-hydroxypyrene in non-smoking university students. Int Arch Occup Environ Health 81: 115-121

Tunsaringkarn, T., et al. 2012. Occupational Exposure of Gasoline Station Workers to BTEX Compounds in Bangkok, Thailand. The International Journal of Occupational and Environmental Medicine. 3: 117-25

Ukai, H., Kawai, T., Inoue, O. 2007. Comparative evaluation of biomarkers of occupational exposure to toluene. Int Arch Occup Environ Health. 81: 81- 93

White, A., et al. 2014. Indoor air pollution exposure from use of indoor stoves and fireplaces in association with breast cancer: a case-control study. Environ Health. 13 (108): 1-12 